$\begin{array}{lll}\text { KULTURA } & \begin{array}{l}\text { POLSKA AKADEMIA NAUK } \\ \text { KOMITET SOCJOLOGII }\end{array} & \text { ISSN 0023-5172 } \\ { } } & \begin{array}{l}\text { INSTYTUT STUDIÓW POLITYCZNYCH } \\ \text { SPOLECZENSTWO }\end{array} & \\ 2011, \text { nr 2-3 SOCJOLOGIA KULTURY } & \end{array}$

BORYS DUBIN

Ośrodek Analityczny Jurija Lewady „Lewada-Centrum”

\title{
POJECIE I FUNKCJE KULTURY W SOCJOLOGICZNYM PROJEKCIE JURIJA LEWADY
}

Pojęcie kultury w klasycznej teorii socjologicznej nie jest wystarczająco opracowane. Większość teoretyków nie uznaje go za pojęcie podstawowe, nawet jeśli jest stosowane, to $z$ reguły ma jedynie znaczenie drugorzędne, pochodne od „społeczeństwa”, „systemu społecznego”, „struktury”, „procesu” lub „grupy” 1 . „Kultura” zaś najczęściej pojawia się w randze systemu — jako „system kultury” lub „system kulturowy”. W taki analityczny sposób jest ona traktowana na przykład w najbardziej rozbudowanej koncepcji socjologicznej ogólnej teorii działania Talcotta Parsonsa i jego zwolenników (Edwarda Shilsa i innych) ${ }^{2}$.

Adres do korespondencji: direct@levada.ru

${ }^{1}$ Projekt świadomej socjologii kultury, oparty na ideach Maksa Webera i Georga Simmla, zaproponowany na przełomie lat siedemdziesiątych i osiemdziesiątych XX wieku przez grupę niemieckich socjologów - Friedricha Tenbrucka, Wolfganga Lippa, Hansa Petera Thurna i innych (zob. L. Gudkow, Kultury socyotogija, w: Sowriemiennaja zapadnaja socyotogia: Stowar', Politizdat, Moskwa 1990, s. 150-150), z dzisiejszej perspektywy niestety nie zmienił tej sytuacji.

2 Zob. T. Parsons, O strukturie socyalnogo diejstwija, Akadiemiczeskij projekt, Moskwa 2000, s. 462-463. Należy wspomnieć, że część przekładów wchodzących w skład tej pracy zbiorowej pochodziła z wydziału Instytutu Badań Społecznych, którym pod koniec lat sześćdziesiątych kierował Lewada, on sam z kolei zawsze wymieniał Parsonsa wśród kilku autorów (Durkheim, Weber, Simmel), na których ideach on i jego współpracownicy uczyli się socjologii; zob. na przykład jego wywiad w książce Rossijskaja socyołogija szestidiesiatych godow $w$ wospominanijach $i$ dokumientach, Russkij christianskij gumanitarnyj institut, Sankt Petersburg 1999, s. 90. Z późniejszych socjologów-teoretyków dla Lewady ważne znaczenie miał Erving Goffman; ponadto Lewada jako jeden $z$ pierwszych, jak się wydaje, w połowie lat siedemdziesiątych sięgnął w ZSRR do prac Clifforda Geertza (referował jego artykuł o ideologii jako systemie kulturowym w Instytucie Informacji Naukowej o Naukach Społecznych). 
Tymczasem „kultura” w historii najnowszej Europy — Jurij Lewada w swoich pracach teoretycznych wielokrotnie o tym wspominał - stała się przedmiotem specjalistycznych badań niemal w tym samym czasie, gdy zwrócono się ku pojęciu społeczeństwa jako samodzielnego, specjalistycznego planu rzeczywistości społecznej, czyli wraz z narodzinami socjologii jako dyscypliny naukowej. Lewada obydwa te wewnątrznaukowe zjawiska rozpatrywał w kontekście wielkiej „dekompozycji historycznej” społeczeństw europejskich podczas przebiegu różnorodnych procesów modernizacji ${ }^{3}$. To, że nauka przyjęła jako punkt wyjścia tę różnorodność struktur społecznych w ich kontekście przestrzenno-czasowym i wzajemnym przenikaniu, pociągnęło za sobą — zgodnie z logiką podejścia Lewady - analityczny podział ogólnych wyobrażeń o działaniu (interakcji) na aspekty społeczne i kulturowe („wyobrażenia zbiorowe”, „formy symboliczne" i inne). Same nauki społeczne zatem, ich powstanie i rozwój, wkładano - według Lewady - w ramy tych procesów społeczno-kulturowych, które czyniły one swoim przedmiotem.

Przedstawmy to bardziej szczegółowo i sformułujmy nieco inaczej, w kategoriach typologicznych. Dopóki społeczeństwo żyje w warunkach mniej więcej jednolitej tradycji, a człowiek w nim, w ścisłych podziałach i przedziałach tego społeczeństwa, jest przydzielony do tego społecznego (jak i geograficznego) miejsca, w którym się urodził, dopóty uogólnione pojęcia społeczeństwa i kultury nie powstają, jak nie powstaje, powiedzmy, u Eskimosów, mających setki słów na określenie rodzajów śniegu, abstrakcyjne pojęcie „śniegu”. Człowiek w takim społeczeństwie (rolnik, wojownik, rzemieślnik, kapłan) „zna swoje miejsce". W zupełnie innej sytuacji znajduje się jednostka w czasach współczesnych: nieprzesądzony bieg wydarzeń jego życia, ciągłe poszukiwania i realizowanie się „wymagają”, można powiedzieć, coraz bardziej ogólnych, elastycznych punktów orientacyjnych i kryteriów oceny działań — ogólnych wartości i norm. Wywołują tym samym coraz większą aktywność grup, które wytwarzają, udoskonalają, rozpowszechniają, podtrzymują podobne wzorce zachowań, myśli i uczuć (wybuchowa dynamika wytworów literackich i prasowych, rynku sztuki, form muzykowania w miejscach publicznych i w ogóle wspólnego spędzania czasu w okresie przejściowym od nowożytności do współczesności niejednokrotnie stawała się przedmiotem badań historyków i socjologów). Instytucje naukowe na swój sposób reagują na to rozszerzające się uniwersum aktualnych okoliczności, wypracowując różnorodne środki konceptualne w celu ich przedstawienia i rozumienia w historycznym starciu, wzajemnym powiązaniu, walce.

3 Zob. J. Lewada, Statji po socyotogii, Moskwa 1993, s. 41, 89 (dalej cytowane jako SS ze wskazaniem strony). Inne zbiory artykułów wykorzystane dalej: J. Lewada, Ot mnienija $k$ ponimaniju. Socyotogiczeskije oczerki 1993-2000, Moskowskaja szkoła politiczeskich issledowanij, Moskwa 2000 (dalej jako MP); J. Lewada, Iszczem czetowieka. Socyotogiczeskije oczerki 2000-2005, Nowoje izdatielstwo, Moskwa 2006 (dalej jako IC). 
Dla historii i socjologii nauki w retrospektywnej analizie ważne jest, jakie dokładnie problemy teoretyk uważa za kluczowe, w jakiego stopnia uogólnienia koncepcjach i kategoriach ujmuje i utrwala te zagadnienia. Dla Jurija Lewady jedną z zasadniczych kategorii w połowie lat siedemdziesiątych stała się „kultura”.

Aby lepiej rozumieć prace teoretyczne Lewady i omawiany tu ich kierunek, należy pamiętać: artykuły Lewady $z$ tamtego okresu były - zgodnie $z$ warunkami i możliwościami czasów - skrycie i jawnie polemiczne, przy czym spór w każdym przypadku dotyczył kwestii zasadniczych. Lewada-teoretyk polemizował głównie $z$ marksizmem (zwłaszcza $z$ ekonomizmem upraszczającym rozumienie działania indywidualnego i zachowania zbiorowego), strukturalizmem $z$ jego traktowaniem kultury jako systemu, behawioryzmem (atomizacją oraz psychologizacją działań społecznych według wzorca bodziec-reakcja), interakcjonizmem symbolicznym $z$ jego rozumieniem społeczeństwa jako systemu wymiany, etnografią krajową z jej uproszczonymi wyobrażeniami o kulturze „materialnej” i „duchowej”. U Lewady w polemice tej najważniejszy konceptualny akcent został położony na pojęcia „kultura”, ”symbol”, „gra” (struktury symboli i gier $\mathrm{w}$ działaniu społecznym), o których będzie mowa dalej.

W późniejszych wywiadach, przywołując ten okres, wskazywał na ówczesną „próbę kulturowo uzasadnionej socjologii”, a w rozmowie z Gennadijem Batyginem wspominał w związku z tym o zwróceniu się - własnym i kolegów — do „kulturologii” ${ }^{4}$. Bardziej szczegółowo kwestia ta została przedstawiona w wywiadzie z 1990 r. przeprowadzonym przez Dmitrija Szalina, opublikowanym już po śmierci Lewady: „[...] niewiele pisałem, ponieważ nie miałem ochoty. Ponadto trzeba było wybrać odpowiedni kierunek, w którym mógłbym rozwijać własne zainteresowania [...]. Nie wolno było publikować na temat socjologii, ale ona już nie tak bardzo interesowała mnie w czystej postaci [...]. Znalazły się ciekawe punkty styczne, z kulturologią, czymś jeszcze" ${ }^{5}$. Następnie mówi o „mniej lub bardziej abstrakcyjnej kulturologii”, którą zaczął się zajmować, i jako opublikowaną wówczas najważniejszą swoją pracę teoretyczną wymienia „artykuł o systemach gier” — Igrowyje struktury w sistiemach socyalnogo diejstwija (1984).

U podstaw nakreślonego przez Jurija Aleksandrowicza Lewadę projektu socjologii teoretycznej — zwięźle go zrekonstruujmy — leżała problematyka strukturalnie złożonego - uwarunkowanego kulturowo, symbolicznie zapośredniczonego - działania społecznego. Anali-

\footnotetext{
${ }^{4}$ Rossijskaja socyotogija szestidiesiatych godow... (SS, s. 89-90; podkr. - B.D.).

5 J. Lewada, "Ja sczitat, szto byto by niejestestwienno wiesti siebia kak-to inacze”, „Socyołogiczeskij żurnał" 2008, nr 1 (http://www.unlv.edu/centers/cdclv/archives/Interviews/levada_90.html).
} 
tycznie wyodrębniano różne poziomy jego sensu, w tym nie przedstawione bezpośrednio wymiary znaczeń - poziom bohaterów historycznych i sankcji mitologicznych (por. znany przykład Lewady z duchem ojca Hamleta, gdy najwyższy poziom znaczenia może być przedstawiony tylko $z$ wykorzystaniem bariery modalnej, jako „inna rzeczywistość”, „cień” - SS, s. 59). Teoretyk snuł rozważania na temat najbardziej skomplikowanych, samocelowych, samowystarczalnych wariantów działania i interakcji (w pierwszej kolejności gry, sztuki) i stosunkowo uproszczonych ich rodzajów - instrumentalnych, ekonomicznych, podlegających obliczeniu, kalkulacji kosztów, optymalizacji środków. Stawiał pytanie o różne modele i typy cywilizacyjne jednostki, charakterystyczny zestaw „postaw i systemów wartości, ram poznawczych i behawioralnych człowieka jako nośnika, substratu określonego systemu instytucji społecznych” — takim jest „człowiek Hellady i człowiek Rzymu, człowiek francuskiego klasycyzmu i człowiek współczesnego (europejsko-amerykańskiego) świata" 6 . Opracowywał problematykę makrospołecznych form przestrzennej i czasowej organizacji społeczeństwa $z$ jego centrum i peryferiami, skomplikowanym systemem czasów społecznych i kulturowych, mechanizmów reprodukcji i źródeł zmian tych form - reprodukcyjny system społeczeństwa, „zbiorowa pamięć”, „zbiorowa wyobraźnia”.

Pisząc w 1984 r. o szczególnej koncentracji współczesnej kulturologii na przeszłości, Lewada podkreślał konieczność „perspektywicznych współrzędnych orientacji kulturowych, wynoszących punkty odniesienia i oceny poza ramy teraźniejszości" (SS, s. 97). Później powrócił do tej kwestii w rozważaniach o „inercyjnym impasie” pierwszego dziesięciolecia XXI wieku, rozwijanych $\mathrm{w}$ artykule z 2004 r. Istoriczeskije ramki "buduszczego" w obszczestwiennom mnienii (IC, s. 62-75).

Przy czym wydaje się, że między pierwszą połową lat siedemdziesiątych i pierwszą połową lat osiemdziesiątych, gdy zostały sformułowane podstawowe i najważniejsze dla późniejszych prac idee teoretyczne Jurija Lewady ${ }^{7}$, głównym społecznym i socjologicznie istotnym zagadnieniem, wokół którego - jako swego rodzaju semantycznego centrum, węzła nerwowego - tak czy inaczej skupiały się wszystkie wyżej wymienione tematy, stało się dla tego badacza zagadnienie reprodukcji systemu społecznego.

${ }^{6}$ Sowietskij prostoj czetowiek. Opyt socyalnogo portrieta na rubieże 90-ch, Mirowoj okiean, Moskwa 1993, s. 6.

7 Niedawne opinie niektórych dziennikarzy i faktografów o tym, że Lewadę w tych czasach jakoby zmuszono do „milczenia”, „odejścia na bok” „usunięcia się w cień”, są niepokojąco pochopne. Bardzo uproszczają sytuację i zupełnie nie odpowiadają rzeczywistości: seminaria odbywały się wówczas regularnie, nie ustawały prace własne teoretyka, ich wyniki były nawet publikowane człowiekiem podziemia Lewada nigdy nie był. Artykuły z tamtych lat w większości były publikowane w niskonakładowych, nie zwracających uwagi pracach zbiorowych, w tym wydanych metodą rotaprintu, a później zostały zebrane we wspomnianej już książce Jurija Lewady Statji po socyołogii. 
Zwrócę uwagę na kilka ważnych cech ówczesnego społeczeństwa, które — jak sądzę - mogły skłonić socjologów do refleksji na temat zdolności reprodukcyjnych systemów społecznych, w szczególności systemu radzieckiego. System ten coraz częściej prezentował się i prezentował siebie — przy czym nie tylko w środkach masowego przekazu i propagandy, ale także w świadomości wielu zwykłych ludzi, jeśli nie większości z nich — jako rzeczywisty i normalny, dobrze ukształtowany i długotrwały. Z jednej strony koła rządzące ZSRR porzuciły politykę totalnej konfrontacji z Zachodem, niepohamowanego wyścigu zbrojeń: w polityce zewnętrznej ogłoszono epokę „odprężenia” i pokojowego współistnienia. $Z$ drugiej strony system niby rezygnował $z$ masowych represji w kraju i utrzymującego się przez kilkadziesiąt lat stanu wyjątkowego w życiu codziennym. Nieprzypadkowe jest w tym kontekście przejście od retoryki światowej rewolucyjnej misji socjalizmu i kładzenia nacisku na komunistyczną perspektywę w przyszłości do podkreślania wagi teraźniejszości.

Kraj stawał się przeważnie miejski, ludność — ogólnie rzecz biorąc — wykształcona (na średnim poziomie) oraz (także na średnim poziomie) zamożna, system komunikacji wyposażany był w nowoczesne masowe technologie medialne (telewizor). Wyrosło pokolenie, które nie doświadczyło historycznych wstrząsów i katastrof (rewolucji, wojen, masowych represji). Dążenie władz, instytucji propagandy i edukacji do nadania ustalonemu porządkowi cech normalnej i stabilnej cywilizacji przejawiało się między innymi w twierdzeniach o „nowej wspólnocie historycznej ludzi, radzieckim narodzie” i ukształtowanym, szczególnym społeczno-antropologicznym substracie tej wspólnoty „człowieku radzieckim" ${ }^{8}$. Zapewnianie siebie i innych o stabilności i trwałości ustroju symbolicznie przejawiało się także w bezalternatywności typu i postaci władzy, niezmienności kierownictwa ${ }^{9}$.

W związku z powyższym przedmiotem badań teoretycznych Lewady stały się mechanizmy czasowej organizacji systemu. W szczególności — sposoby zachowania, podtrzymywania i przedstawiania (retrospektywnego wskazywania na aktualność) jego „przeszłych”, nieobserwowalnych, ale istotnych stanów

${ }^{8}$ Nie omawiam tu, jak te postulaty ideologiczne miały się do ówczesnego życia codziennego. Zaznaczę tylko niezmienne zainteresowanie Lewady fenomenem podwójnej świadomości (późniejszy artykuł Czełowiek tukawyj, w: MP, s. 508-529) oraz ukrytymi mechanizmami deficytu, drugiej rzeczywistości czarnego rynku (wspólna praca z A. Lewinsonem, artykuł „Pochwalnoje stowo” dieficytu, „Gorizont” 1988, nr 10, s. 26-38).

${ }^{9}$ Zob. B. Dubin, Lico epochi. Brieżniewskij pieriod w stołknowienii razlicznych ocenok, „Monitoring obszczestwiennogo mnienija” 2003, nr 3 (65), s. 25-32; A. Bieriełowicz, Siemidiesiatyje goda XX wieka: rieplika $w$ diskussii, „Monitoring obszczestwiennogo mnienija” 2003, nr 4, s. 59-65. 
i cech. Stąd zainteresowanie Lewady mechanizmami tradycji, ujawnione już zresztą $\mathrm{w}$ artykule encyklopedycznym $\mathrm{z}$ końca lat sześćdziesiątych (SS, s. 21-23), gdzie zauważał, że w bardziej rozwiniętych, nowoczesnych społeczeństwach obszar znaczenia tradycji ogranicza się do określonych stref stosunków etnicznych, nakazów rodzinnych, organizacji wojskowych i podobnych. W skali całego społeczeństwa zaś oddziaływanie tradycji dopełnia się działaniem innych, mniej „bliskich” i „widocznych”, ale bardziej uniwersalnych sposobów reprodukcji struktury społecznej - na przykład prawnych. Innymi słowy, tradycja $\mathrm{w}$ tych społeczeństwach, $\mathrm{w}$ przeciwieństwie do społeczeństw właściwie tradycyjnych, jest już częściowa, a nie totalna, obszary jej wpływu, stanowczości, bezdyskusyjności są różnie zaznaczone dla różnych grup. Inną ważną właściwością jest to, że tradycja podlega tu in terpretacji, w tym specjalistycznej, lecz nie tylko, dlatego może być pozbawiana treści przez sprowadzanie do wyłącznie zewnętrznego (ceremonialnego, imitacyjnego) jej przestrzegania lub wyłącznie ustnych zapewnień o wierności - nakazom, autorytetom itp.

Problem przejścia od symboli „bogatych w treść” do „pustych” bardzo interesował Lewadę. Został rozpatrzony na przykład na materiale empirycznym w późniejszym artykule o symbolicznych strukturach opinii publicznej (IC, s. 188 i nast.). Tu między innymi wprowadza się pojęcie „mitu społecznego": to właśnie ono służy charakterystyce ideologicznych lub utopijnych (według Karla Mannheima) konstrukcji, które reprodukują „w świeckim, współczesnym materiale strukturę i niektóre funkcje pierwotnych, kulturowych wzorców" (IC, s. 190-191). Innymi słowy, wspomniane powyżej „pozbawienie treści” to nie tylko odchylenie od "prawidłowego" działania mechanizmu społecznego, „awaria” systemu. Może być rozpatrywane w sposób ogólny — jako społeczno-kulturowy i społeczno-historyczny proces wiodący od tradycji i kultu przez ideologię i ceremoniał do gry. Określenie działań zbiorowych jako gry, jak niejednokrotnie podkreślał Lewada, nie pozbawia ich grozy, powagi, a nawet tragiczności - takiego rodzaju groźnym grom poświęcony był artykuł Lewady o zamieszkach w 2002 r. na ulicach Ochotnyj Riad i Twierskaja w centrum Moskwy, w pobliżu Dumy Państwowej, kilka kroków od Kremla ${ }^{10}$.

Podkreślam jeszcze raz: Lewada to nie historyk i nie kulturolog. Interesuje go specyficzna rzeczywistość socjologiczna - sposoby organizacji współpracy ludzi i społeczności, mechanizmy podtrzymywania tych form, kierunki i czynniki ich transformacji, przeobrażenia, rozpadu. Jest socjologiem, widzi i myśli socjologicznie. Zajmuje go w tym przypadku nie semantyczna konstrukcja tradycji, jej geneza itd., ale jej oddziaływanie i funkcja w ramach działania grup społecznych, instytucji, ruchów.

10 Zob. J. Lewada, W kakije igry igrajut totpy, „Monitoring obszczestwiennogo mnienija” 2002, nr 4, s. 59-61. 
Lewada zwraca szczególną uwagę na przykład na odwołanie do tradycji w programach i rytuałach współczesnych ruchów nacjonalistycznych i faszystowskich, wspominając o „stosowaniu tradycyjnych form w celu legitymizacji w gruncie rzeczy nietradycyjnych stosunków" (SS, s. 22) ${ }^{11}$. Później zajmowało go charakterystyczne odwrócenie tej zbiorowej praktyki - tak samo paradoksalne zrastanie się „starego" i „nowego” w tak skrajnej sytuacji jak atak terrorystyczny 11 września $2001 \mathrm{r} .{ }^{12} \mathrm{Tu}$, przeciwnie, najbardziej nowoczesne środki zachodniej techniki (nie tylko samolot pasażerski i najnowsza broń, ale także środki masowego przekazu - przede wszystkim telewizja z jej technologią tworzenia wiadomości, fabrykowania sensacji i „gwiazd”, ich reklamy, promocji itp.) - zostały wykorzystane przez agresywnych islamskich radykalnych nacjonalistów przeciw Zachodowi. A wszystko to uzasadniane lojalnością wobec „tradycji islamu” i koniecznością uciekania się do skrajnych środków ich „obrony”.

Zagadnienie, które stanowiło inspirację dla rozpatrywanych tu prac Lewady, dotyczyło, jak sądzę, nie tyle podtrzymywania wzorca systemu, ile wyboru celów i strategii działania, optymalizacji sposobów osiągania znaczących wyników. Krótko mówiąc, za cel uważał on nie to, by zachowywać, lecz by podążać dalej (jeszcze raz przypomnę wspomnianą wyżej wypowiedź o „perspektywicznych współrzędnych orientacji kulturowych”).

Rozgraniczenie wskazanych planów należy, oczywiście, do analityka, ale w kategoriach analizy środkami konceptualnymi utrwala się tu przebieg bardziej ogólnego procesu społeczno-historycznego — podziału działania według zachowania wzorców relacji wzajemnych (Lewada odnosił je do „programu kultury”) oraz działania według osiągania celów (według Lewady — „programu doświadczenia") ${ }^{13}$. W sporach publicznych i prywatnych toczonych w latach sześćdziesiątych i siedemdziesiątych na temat ideologicznie przeciążonego pojęcia kultury — o „fizykach” i „lirykach”, „dwóch kulturach” (odsyłacz do książki C. P. Snowa pod tym tytułem znajduje się w artykule z 1998 r. MP, s. 307) - Lewada nie zajmuje żadnej z dwóch narzucanych pozycji, lecz proponuje bardziej złożone spojrzenie na temat różnicy zdań.

Tłumienie impulsów do optymalizacji systemu społecznego (poszukiwań nowego, rozważania opcji, wyboru optymalnego) w ostatecznym rozrachunku

11 Artykuł Faszyzm (SS, s. 123-135) pochodzi z tego samego okresu, co artykuł Tradicyja, także przeznaczony dla ostatniego, napisanego bardziej swobodnie niż wcześniejsze i dlatego najbardziej bogatego w treści piątego tomu Fiłosofskoj encykłopiedii (wydanej w 1970 r., przygotowanej pod koniec lat sześćdziesiątych).

12 Artykuł z 2002 r. Otłożennyj Armagieddon? (IC, s. 91-114).

13 SS, s. 52 i nast. 
prowadzi do zakłócenia jego reprodukcji (funkcji zachowywania i utrzymywania całości). U podstaw współczesnych społeczeństw, w ich funkcjonalnych centrach, głównych instytucjach — od mechanizmów rynkowych po struktury edukacji, znajdują się właśnie funkcje wyznaczania celów, osiągania celów, optymalizacji działania systemu $\mathrm{w}$ jego relacjach $\mathrm{z}$ innymi systemami (przy czym uogólnione kryteria wyboru i oceny optymalnych rozwiązań należą, oczywiście, do programu kultury - wspótczesnej kultury). Oznacza to, że system, który przestaje odpowiadać na wyzwania teraźniejszości i wyznaczać sobie nowe cele, snuć plany, wybierając optymalne strategie, przeradza się w ceremoniał, zamkniętą grę według zasad formalnych. Był to jeden z powodów tego, że w pierwszej połowie lat osiemdziesiątych Lewada zwrócił się ku pojęciu gry. Odnoszące się do tego punktu idee przedstawione w jego artykule z 1984 r. na temat struktur gry (SS, s. 99-119), zostały później rozwinięte w rozważaniach o symbolu i rytuale (lub ceremoniale) sformułowanych już w pierwszych latach XXI wieku — w artykule Ludi i simwoty z 2001 r. (IC, s. 188-191); daty obu prac wydają się bardzo znaczące.

Desymbolizacja działania społecznego, sprowadzanie programu kultury jedynie do operacyjnej orientacji w bieżącej rzeczywistości i do wyłącznie reaktywnej adaptacji do jej wymogów także niszczy społeczeństwo jako system. Dezaktualizacja przeszłości, utrata zdolności społecznych (przede wszystkim przez grupy postępowych intelektualistów) do ponownego „pytania” i reinterpretacji „odpowiedzi” przekształca kulturę w szanowane, ale niezbyt często odwiedzane muzeum lub w reprezentacyjną wystawę-galerię „generałów” (według sformułowania Jurija Tynianowa). Oznacza to, że degradacja społeczeństwa zachodzi zarówno w sferze możliwej optymalizacji systemu (i rezygnacji z systemu nowego), jak i pamięci o przeszłości (i muzeifikacji przeszłości). W obu planach działania - a dla Lewady fundamentalne znaczenie ma ta wielowymiarowość, zawsze problematyczne sprzężenie różnych planów działania, poziomów jego racjonalizacji - analityk odnotowuje niezdolność do nowego, rezygnację ze złożoności, a więc i z ruchu, z czasu (historycznego czasu działania, który zawsze jest $\mathrm{w}$ teraźniejszości, ale też związany jest $\mathrm{z}$ przeszłością i przyszłością, z projekcjami „W obie strony” od współczesności). W tym upatruję sens tego, jak Lewada sięgał do kategorii cyklu lub, dokładniej mówiąc, cykli społecznego czasu i rytmów ich kolejności, zmiany. W „zastygającym” systemie poszukiwane były punkty ewentualnej dynamiki; w niezmienności niekończącego się, jak się wydawało, powtarzania się teraźniejszości szukano wyjścia z błędnego koła „inercyjnego impasu”.

Jeśli tradycję można analitycznie przedstawić jako jedną z granicznych form organizacji działania (i społeczeństwa jako systemu interakcji), to inną granicą socjologicznej analizy, według Lewady, jest gra. Tradycja jest bezalter- 
natywna (nie zawiera odniesień do niczego „zewnętrznego”, „odmiennego”), widoczna i stanowcza („rób tak!”), totalna (obejmuje cały kształt życia zbiorowego), działania nie są podzielone $w$ niej na praktykę i rozumienie. Nie ma więc wyodrębnionego systemu edukacji, jakiegoś odpowiednika szkoły, tak jak nie jest oddzielony od codziennego życia społeczności tradycyjnych obszar wyższych sankcji postępowania, sfera sacrum (rozpowszechniony obyczaj pochówku przodków rodziny pod progiem rodzinnego domu — wyraz nierozerwalnej bliskości „tego” i „tamtego” świata). Podobne cechy pozwalają socjologowi warunkowo, w danych ramach analitycznych, rozpatrywać tradycję jako stosunkowo prostą, elementarną formę (zasadę) organizacji społecznej.

Gra z kolei stanowi dla socjologa skomplikowaną, być może nawet bardzo złożoną, formę interakcji społecznej, strukturę jej organizacji. Ale jednocześnie niesie ze sobą wiele - oczywiście, funkcjonalnie przetransformowanych i merytorycznie przemyślanych - cech struktury elementarnej. Przede wszystkim zamkniętość, brak odniesień: „[...] ramy normatywne i orientacje zadaniowe [...], odpowiednie motywy i interesy [których] nic nie definiuje, oprócz samej gry [...] bezsporność systemu zasad gry, obowiązków, długów" (SS, s. 100). Jednak zamkniętość struktury gier $\mathrm{w}$ tym przypadku jest związana $\mathrm{z}$ tym, że jest ona złożona, wielowymiarowa. Zawiera kilka poziomów znaczeń, z których jedne uzasadniają lub sankcjonują inne, umożliwiają przejście dalej lub zakazują go, służą za symboliczną barierę lub operator działania.

Proces oddziaływania sztuki nie ogranicza się więc do komunikacji w sensie przekazu informacji: akt recepcji musi obejmować plan nie tylko powiadamiania, ale i oswajania. Lewada cytuje bułgarskiego poetę Atanasa Dalczewa: „Poezja to nie obcowanie, ale oswajanie. Oswajanie z Ideą, Pięknem, Prawdą. Na tym polega różnica między listem a poematem" (SS, s. 94). Innymi słowy, przekazywana jest nie tylko treść (zawartość) komunikacji, a jednocześnie proces ten nie sprowadza się też do aktu integracji $z$ wyobrażonym idealnym społeczeństwem w warunkach uczestnictwa we wspólnym dziedzictwie symbolicznym. Sens aktu (jeśli był udany!) polega na połączeniu dwóch planów, które właściwie stanowią dla odbiorcy fakt jego uspołecznienia i kultury.

W podobny sposób przedstawia Lewada ogólnie strukturę działania społecznego jako takiego (strukturę „pełną”, nie sprowadzaną tylko do strony ekonomicznej, kalkulowanej). Obejmuje ona nie tylko składniki instrumentalne (środki osiągnięcia celu, formy równoważnej wymiany) i nie tylko wzorce zachowań (normatywne sankcje cieszących się autorytetem grup, ich hierarchiczne definicje rzeczywistości). Działanie wyrażane jest poprzez symbole, które włączają działającego do systemu kultury, pośredniczą w przejściu na inny poziom (typ) sankcji lub zawierają „odniesienie do "reguł gry» innej kategorii” (SS, s. 93) - symbole działają (oznaczaja) w „imieniu” uogólnionych wartości, już niezwiązanych z określonym autorytetem (osoba) lub stylem życia jakiejś jednej grupy (władzy, inteligencji). Tylko takie wielowymiarowe sprzężenie stanowi komórkę pełnowartościowej struktury działania. Sprowadzenie działania 
do jednego $z$ modelowych biegunów zmienia je w rytuał (grę, ceremoniał) lub wyłącznie w wymianę ${ }^{14}$.

Lewada podkreślał (znowu w polemice ze strukturalizmem oraz z koncepcją ról społecznych, modelem „człowieka socjologicznego” Ralfa Dahrendorfa, „perspektywą dramaturgiczną" w socjologii), że gra to nie model. Nie ma ona funkcjonalnego znaczenia poza samą sobą, nie stanowi wzoru dla jakiegokolwiek działania niezwiązanego z grą („Samowystarczalność struktur gry nie pozwala traktować ich jako symboli jakiejś innej rzeczywistości" — SS, s. 103), chociaż działanie niezwiązane $z$ grą może nabierać cech gry - na przykład imitować grę, przejmować jej modalność lub poszczególne elementy.

Lewada do własnych celów wyróżnia takie poziomy znaczeń w grze, jak operacyjny (celowy, instrumentalny, system zasad), behawioralny (dynamika działań i stanów, kolejność następstwa i zmiany - formy organizacji przestrzeni i czasu), socjologiczny (struktura roli, formy instytucjonalizacji gry). Wśród instytucjonalnych form działań opartych na grze - „gry z publicznością" - Lewada skupia się na dwóch głównych, a mianowicie na sporcie i teatrze. Ich analiza porównawcza pozwala mu wyodrębnić matrycową wielowymiarową strukturę działania związanego $\mathrm{z}$ grą. Łączy ona $\mathrm{w}$ sobie wymiar celów i roli, przy czym właśnie wymiar roli („teatr”) stanowi warunek, wyzwalacz (trigger) lub swojego rodzaju przepustkę upoważniającą do przejścia do innego, instrumentalno-zadaniowego poziomu znaczeń („osiągnięcie sportowe”, „zwycięstwo”, „wynik”). Krótko mówiąc, teatralizowane rozpoczęcie zawodów sportowych łączy widzów wokół widowiska sportowego i w tym symbolicznym geście symbolicznej jedności z drużyną i innymi kibicami przyjmują oni, utrwalają i podtrzymują właśnie instrumentalne aspekty działania, które, jak już wspominałem, dla współczesnego społeczeństwa i współczesnej kultury są fundamentalne. Współzawodnictwo (dążenie do osiągnięć) jest tu pochodną solidarności, a solidarność umacniana jest przez widoczne rezultaty wspólnych wysiłków - osiągnięte zwycięstwo ${ }^{15}$.

Stąd niezmienna widowiskowość, demonstracyjność nie tylko sportu, ale całej współczesnej kultury (ideologiczni krytycy modernizmu i kultury modernistycznej wprowadzają w celu ich charakterystyki „narcyzm” jako kategorię ocenną - nieprzypadkowo w XIX wieku narodziły się wystawy i muzea, fo-

14 Na przykład prostytucja znosi symboliczną hierarchię, w tym kokieterię, rytuały zalotów, pojęciowej gradacji działań i rozmieszczania ich na osi czasowej — jako stadium krystalizacji i narastania uczucia, gry na zwłokę i ustępstwa, kulminacji itp. Tym samym znosi afekt będący celem lub bodźcem przygód. Usunięcie wyobrażanej bariery (symbolicznie pokonywanej w grze miłosnej, lecz zawsze obecnej w tym pokonywaniu) przerywa akt komunikacji i jakby anuluje fakt socjalności - figurę „znaczącego innego” i siebie w stosunku do niego, pozbawia zdarzenie znaczenia i sensu. Afekt nie jest wymienialny na pieniądze, a pieniądze - na afekt; cena nie tworzy wartości (lecz na odwrót).

15 Zob. B. Dubin, Sostiazatielnost' $i$ solidarnost'. Rożdienije sporta iz ducha obszczestwa, „Otieczestwiennyje zapiski" 2006, nr 33 (6), s. 100-120. 
tografia i wystawy sklepowe). Kultura jako symboliczne uosobienie teraźniejszości, jej „ducha”, mówiąc starym filozoficznym językiem, jest konstytuowana i wewnętrznie organizowana właśnie przez ciągłe odwoływanie się do różnych i uogólnionych partnerów, istniejących i wyobrażanych, czym różni się od tradycyjnej, zamkniętej klasowej lub korporacyjnej organizacji. Systematyczne kultywowanie podstaw i zasad socjalności, solidarnej i jednocześnie rywalizacyjnej interakcji, z jednej strony, i tak samo systematyczne kultywowanie otwartości, publicznego charakteru, nakierowania zachowania na licznych i różnych „innych” z drugiej stanowią, w sprzężeniu, semantyczne jądro projektu „modernizmu” i uzasadniającej go „kultury”. Stąd rola „zewnętrznego”, wizualnie przedstawionego w epoce modernistycznej, w której, co jest znamienne, były tworzone, rozpowszechniane, zakorzeniane ogólnodostępne, technologiczne, wizualne środki masowego przekazu ${ }^{16}$.

Problematyka widowiska, gry dla publiczności bardzo zajmowała Lewadę W związku z ogólnoświatowymi procesami upowszechniania się kultury masowej, a także z pierwszymi przejawami masowego społeczeństwa w Związku Radzieckim $\mathrm{w}$ pierwszych latach pierestrojki $\mathrm{z}$ jednej strony oraz w związku $z$ fenomenem „demokracji widzów” lub „telewizyjnej demokracji” w Rosji $z$ drugiej. W podobnym fenomenie wyłącznie telewizyjnego uczestnictwa widzów w życiu społecznym i politycznym Lewada upatrywał nowy typ aktywności społecznej, ważny dla współczesnych społeczeństw: „szczególny rodzaj gry społecznej - jedno z głównych osiągnięć XX wieku, prawdopodobnie porównywalne $z$ wynalezieniem rysunku i pisma, nie mówiąc już o teatrze, sporcie i innych" (MP, s. 313).

Niezrozumiałe i bezpłodne dyskusje o „materialnej” lub „duchowej”, „wysokiej” lub „niskiej” kulturze itp. Lewada zaliczał tym samym do „archaicznych" faz i zalążkowych form refleksji nad kulturą ${ }^{17}$. Kontynuowanie ich na serio w dzisiejszych warunkach uważał za zajęcie całkowicie bezproduktywne ${ }^{18}$.

16 Zob. B. Dubin, Wizualnoje $w$ sowriemiennoj kulturie, w: Intielektualnyje gruppy $i$ simwoliczeskije formy. Oczerki socyologii sowriemiennoj kultury, Nowoje izdatielstwo, Moskwa 2004, s. 31-37 (zob. także wymienioną tam literaturę).

17 „Na bardziej zaawansowanych etapach rozwoju socjologicznej analizy kultury powstaje problem opracowania adekwatnych metodologicznych środków badania ściśle kulturowych struktur i procesów" (SS, s. 98; podkr. - B.D.).

${ }^{18}$ Za niesamodzielne teoretycznie uważał Lewada także rozpowszechnione w latach siedemdziesiątych, częściowo pod wpływem strukturalizmu i semiotyki, traktowanie kultury jako systemu — „niezamierzony produkt reifikacji (urzeczowienia) narzędzi badawczych” — zauważał Lewada i kontynuował: „Ani empiryczne, ani metodologiczne rozważania nie pozwalają przypisać ontologicznego statusu realnego, to znaczy funkcjonującego, «działającego» systemu czemukolwiek innemu oprócz organizmów i organizacji ("zorganizowanych elementów») różnego rodzaju, posiadających określone mechanizmy funkcjonalnego związku, realne nośniki takich związków itd." (SS, s. 90). Jednocześnie pojęcie „potrzeb kulturowych” („społecznie niezbędnych potrzeb”), które weszło do ówczesnej praktyki zarządzania kulturą, i zawodowy żargon obsługujących tę sferę grup specjalistów-socjologów Lewada oceniał jako ekonomizację wyobrażeń o społecznym działaniu i kulturze, autorytatywną „redukcję złożoności”, która neguje i wyklucza zasadniczy nadmiar (we- 
Dla niego były to rytuały gry w naukę. Skargi na zacieranie się granic między elitarnym a masowym, na niszczenie wzorców „wysokiej kultury” lub podważanie „narodowych fundamentów” - produkty nie rozpadu świata, lecz rozkładu inteligenckiej ideologii. Lewada skupiał się na czymś innym - na zmianie mechanizmu oddziaływania wzorców (MP, s. 320), upadku „kultury państwowej”, jak sam to ujął, na nasilaniu się wzajemnego wyobcowania ludzi i grup („bierny indywidualizm”), narastaniu społecznej obojętności i cynizmu w Rosji.

Jako zdezaktualizowany przypadek gry Lewada traktował ceremoniał polityczny, „rytuał pozbawiony swoich "pionowych» funkcji” (SS, s. 103) - demonstrację bezalternatywnej władzy politycznej oderwanej od stosunków społecznych i kontekstu historycznego, bez wyznaczania wspólnych celów i planów ich osiągnięcia, wyłącznie jako zogniskowanie wyobrażanej integracji z nią najbliższych kręgów i większości ludności. Sensem działania staje się tu jego granica, która jakby wchodzi do centrum (mówiąc inaczej: symbol, symboliczny pośrednik nie odsyła do innego, bardziej wartościowego planu działania, na przykład nie oswaja $z$ głębią dziejów lub sferą kultury, lecz sam zmienia się w „granicę działania” - sytuacja, którą Lewada opisuje jako „zdezaktualizowaną" SS, s. 70). Stanowiąc semantyczny ośrodek działania (interakcji), reprodukuje ona i podtrzymuje sytuację rozłamu społecznego, pęknięcia socjalności, ponieważ oddziela "nas” od „nich” i narzuca skrajnie prosty wzór hierarchicznego systemu odizolowanego od świata zewnętrznego i różnorodnych figur „znaczących innych". W takiej postaci może ona tylko imitować, zwielokrotniać samą siebie na poziomie społeczno-przestrzennym („w regionach”, „na szczeblu lokalnym") oraz w granicach innych zbiorowości (np. w rodzinie czy szkole). W tych kategoriach Lewada opisywał później między innymi charakter władzy, typ społeczeństwa i zachowanie człowieka masowego w Rosji początku XXI wieku (IC, s. 188-191) — odwołanie się do konceptualnych rozważań z 1984 r. wydaje się, powtarzam, absolutnie nieprzypadkowe.

Temat ciągłości i zmian, źródeł i mechanizmów zmiany, form instytucjonalizacji wartości i idei został znacznie rozwinięty i skorygowany w drugiej połowie lat osiemdziesiątych, w kontekście przemian społeczno-politycznych rozpoczętych w kraju z inicjatywy Michaiła Gorbaczowa i jego współpracowników. W warunkach społecznych lat 1988-1989 Lewada odwołał się do pojęcia

dług Lewady „ponadkonieczność”) wzorców kultury, nieodwołalność, a także nieprzewidywalność, osobistego wyboru podmiotu wśród tej różnorodności. Te polemiczne konteksty myśli autora, których ze względu na ówczesne okoliczności nie można było wyrazić w pełni (krytyka semiotyki byłaby niezwłocznie przywłaszczona przez oficjalne kręgi), należy rozumieć i uwzględniać: teoria to także działanie społeczne (interakcja). 
„społecznego przełomu” lub, jak jeszcze go nazywał, avalanche ${ }^{19}$. W ten sposób nie tylko opisał pierwsze wielkie zmiany w radzieckim społeczeństwie („powszechne negowanie przeszłości"), ale także zaproponował rozpatrywanie ich jako dynamicznej struktury ze swoją logiką, elementami składowymi, wieloma parametrami oraz działającymi w różnym czasie czynnikami, wraz z bodźcami inicjującymi o różnym nasileniu i szybkości działania (problem przywództwa i wsparcia, rola „inteligencji” ${ }^{20}$ ) oraz mocy hamowania społecznego - wśród nich wymieniał między innymi „biurokrację" ${ }^{21}$.

W kwestii inteligencji Lewada nie podzielał złudzeń rozpowszechnionych w czasach sowieckich i postsowieckich wśród warstw wykształconych. Rzeczywiste istnienie inteligencji skończyło się dla niego w latach dwudziestych, potem rozpoczął się „okres fantomowy” (SS, s. 157), gdy grupa ta utraciła swoją tożsamość, zachowując (lub przywłaszczając nie należącą do niej) nazwę. W tym kontekście Lewada podkreślał marginalną pozycję dysydentyzmu i wszelkich innych form przeciwstawiana się władzy i jej oficjelom w czasach sowieckich - przytłaczająca większość zaliczających siebie do inteligencji przyjęła adaptacyjną taktykę obsługiwania władzy i ustalonych przez nią form zbiorowego istnienia.

Tak czy inaczej w dzisiejszych czasach zachowywanie, podtrzymywanie i rozpowszechnianie kultury coraz bardziej staje się funkcją wielkich, anonimowo działających systemów instytucjonalnych, którym nie przypisuje się niczego osobistego, heroicznego czy po prostu wzorcowego. Ponadto w warunkach postsowieckich systemy te, bazujące na tekstach drukowanych i normach kultury pisanej (od szkół po biblioteki), ulegają całkowitemu rozpadowi, a związane $z$ nimi warstwy wykształcone tracą prestiż i autorytet: typowa tu jest znikoma atrakcyjność dla dzisiejszej rosyjskiej młodzieży i pokolenia jej rodziców roli nauczyciela jako przyszłego zawodu. Najbardziej dotkliwie odczuwają to właśnie wczorajsi pretendenci do roli elity kulturalnej: ich kulturowy monopol i uzasadniające go wsparcie państwowe drastycznie się skurczyły. Jednocześnie przeważająca większość ludności Rosji obecnie regularnie ogląda telewizję po 3-4 godziny dziennie (i po 4-5 godzin w weekendy). Telewizja w Rosji cieszy się zaufaniem większym niż inne współczesne instytucje społeczne, zwłaszcza instytucje nowe w rosyjskiej rzeczywistości (partie, władza prawodawcza i wykonawcza, stowarzyszenia). Na telewizję, jej kanały, osoby prowadzące ludzie narzekają tak samo często jak na wszystko inne, ale jednocześnie, co jest charakterystyczne, nadal regularnie i długo wpatrują się w ekran. Oglądanie telewizji jest formą symbolicznej integracji rozpadającej się

19 Zob. Dinamika socyalnogo pieriełoma: wozmożnosti analiza (SA, s. 159-175).

20 Zob. J. Lewada, Problema intielligiencyi w sowriemiennoj Rossii, w: Kuda idiot Rossija?: Altiernatiwy obszczestwiennogo razwitija, Intierpraks, Moskwa 1994, s. 208-214.

21 Zob. Biurokratizm i biurokratija: nieobchodimost' utocznienija (SS, s. 136-155). 
zbiorowości Rosjan w wyimaginowaną całość - „społeczeństwo widzów” 22 . Doświadczamy właśnie tego, co Lewada wiele lat temu opisał wyłącznie jako model teoretyczny: symboliczny pośrednik zmienia się w "granicę działania”, a działanie "tym samym nabywa cech specyficznie symbolicznego (gra, rytuał)" (SS, s. 70).

Stąd naukowe zainteresowanie Lewady przeciętnym człowiekiem (godzącym się „być jak wszyscy”) i kulturą masową odpowiadającą tym nastrojom i „przeciętnym” gustom. Lewada podkreślał prostotę wzorów kultury masowej. Symbole transmitowane przez kanały masowego przekazu odnoszą się do podziału na „swoich” i „obcych”, „wyższych” i „niższych”. Prymitywizm podobnych wzorców i podtrzymywanych za ich pomocą podziałów społecznych w najbardziej bezpośredni sposób zapewnia ich trwałość i skuteczność (przyswajalność). Jeśli w latach dziewięćdziesiątych takimi symbolami były slogany przeciwstawiające przeszłość i teraźniejszość (władza i jej demokratyczne otoczenie przeciwko komunistom i mobilizowanym przez nich biernym masom), to pod koniec dziesięciolecia, a zwłaszcza w nowym stuleciu, na pierwszy plan trafiły symbole stabilności i jedności wewnętrznej kraju, a figury retoryczne konfrontacji zaczęły przenosić się na „wrogie otoczenie” Rosji, od krajów bałtyckich po Stany Zjednoczone. W pracy upaństwowionych mediów, cenzurowanych zarówno od zewnątrz, jak i od wewnątrz, dziś znowu widoczne są próby nadania aktualności ideom „odrębnej drogi” Rosji i pewnego pozytywnego, tylko jej jedynej znanego sensu — coraz większego wykluczenia kraju z ogólnego światowego ładu (artykuł Czełowiek sowietskij kak czełowiek „osobiennyj” - IC, s. 312-321).

Dla Jurija Lewady wszystko to określało socjologiczne znaczenie problematyki „człowieka” - „zwykłego”, „przeciętnego człowieka” z jego przewrotnością i samoograniczeniem, niezadowoleniem i nostalgią, dwutorowością myślenia i nieufnością; zmuszało do koncentrowania się na badaniach mechanizmów reprodukcji tego typu człowieka w warunkach oczywistej nieodtwarzalności represyjnego totalitarnego porządku, który ukształtował ten model społeczno-antropologiczny oraz na studiowaniu adaptacyjnych w swoich postawach „elit” podtrzymujących ten stan. Na tym, jak wydaje się, polega sens jeszcze jednego, niedawnego zwrócenia się Jurija Lewady do kategorii elit i mas w szczegółowym i bezkompromisowym, jednocześnie ostatnim artykule autora ${ }^{23}$.

\section{Tłumaczenie Katarzyna Baradai}

22 Zob. L. Gudkow, B. Dubin, Obszczestwo tielezritielej: massy $i$ massowyje kommunikacyi $w$ Rossii konca 90-ch godow, „Monitoring obszczestwiennogo mnienija” 2001, nr 2, s. 31-45; B. Dubin, Mass-medija i kommunikatiwnyj mir żytielej Rossii: ptasticzeskaja chirurgija socyalnoj riealnosti, „Wiestnik obszczestwiennego mnienija" 2006, nr 3 (83), s. 33-46.

23 Zob. pracę Elitarnyje struktury $w$ postsowietskoj situacyi, będącą pierwszym rozdziałem zbiorowej monografii: L. Gudkow, B. Dubin, J. Lewada, Problema „elity” w siegodniaszniej Rossii, Fond Libieralnaja missija, Moskwa 2007. 


\section{NOTION AND FUNCTIONS OF CULTURE IN YURIJ LEVADA'S SOCIOLOGICAL PROJECT}

Summary

The article features an analysis of the ideas of Yurij Levada, an eminent Russian academic, sociologist dealing both with theory and with practice of sociology, a founder of a research institution in Moscow known as Levada-Centre. Levada gave a special place to culture within sociology and he himself called his project on theoretical sociology an "attempt at culturally justified sociology" (grounded in a perspective orientated to culture). The project was based on structurally complex, culturally conditioned and symbolically indirect social actions. In his opinion, such knowledge of culture required to be looked at retrospectively, which provides for tackling the issue of social system reproduction while enabling to understand contemporary culture at the same time. This way of thinking was a basis for Levada's analyses of the surrounding social reality, e.g. his analyses of intelligence or the concept of "simple Soviet man".

\section{Key words/słowa kluczowe}

Yurij Levada / Jurij Lewada; sociological theory / teoria socjologiczna; culture / kultura; Russian society / rosyjskie społeczeństwo 